\title{
New Criteria for Chemical Heterogeneity of the Biosphere: Distribution of Cadmium and Lead in Laying Hens
}

\author{
Veselin Kirov $^{1 *}$, Abdul Karim Hallak ${ }^{2}$, Alexander Tchoukanov ${ }^{3}$ and Bayko Baykov ${ }^{1}$ \\ ${ }^{1}$ University of Forestry, Faculty of Veterinary Medicine, Kliment Ohridski Street 10, \\ Sofia 1756, Bulgaria \\ ${ }^{2}$ Ministry of Agriculture, Damascus, Animal Drugs Direcorate, Department quality control \\ laboratory, Damask \\ ${ }^{3}$ University of Ontario Institute of Technology, Faculty of Health Sciences, 2000 Simcoe Street \\ North Oshawa, Ontario, Canada \\ *Corresponding author
}

\section{A B S T R A C T}

\section{Keywords \\ Chemical heterogeneity, biosphere, food chain, toxic elements, $\mathrm{Pb}, \mathrm{Cd}$, food safety \\ Article Info \\ Accepted: \\ 16 May 2018 \\ Available Online: \\ 10 June 2018}

Trials are made with laying hens divided into 4 groups, which are being given rations containing lead and cadmium corresponding to those existing in regions with high technogenic Clark. Two new criteria are proposed for improvement of the efficiency of anthrozoocenosis management, which define the chemical heterogeneity of the biosphere at organism and sub-organism level: distribution Clark and safety Clark. Differences are found both in the organotropism of tested elements and in their distribution. The criterion safety Clark shows some irregularities in the legal regulations with regard to the cadmium content of the laying hen products.

\section{Introduction}

At the end of the $19^{\text {th }}$ century Clark found that the lithosphere is chemically heterogenic. During the $20^{\text {th }}$ century Vernadsky proved that the chemical heterogeneity is a feature of the entire biosphere as well: both for abiotic components (lithosphere, hydrosphere and atmosphere), and for living matter. During the second half of the century, authors emphasized on an issue exposing the populations and biocenoses at risk: increased content of chemical elements in the living environment, i.e. the anthropogenic redistribution of chemical factors in the biosphere poses risks for the human health and for the biocenosis values due to their accumulation along the food chain.

The purpose of this publication is to suggest appropriate criteria defining the chemical heterogeneity of the biosphere when managing the anthropozoocenoses for the purposes of mitigating the environmental risk in the case of increased cadmium and lead content in the living environment. These studies are based 
on the further development of Vernadsky's theory about the chemical heterogeneity of the biosphere at the biosphere and ecosystem level. Expanding the scope of the studies up to the organismal and sub-organismal structural level with new quantitative criteria will allow for the improvement of the efficiency of the anthropogenic ecosystem management and food safety and control.

\section{Materials and Methods}

Trials are carried out with laying hens under modelled conditions. Models are of mesocosm type as per the Odum's classification /1986/. The ecotope is an air-conditioned production building with size 20/10 m where all groups of birds are being bred simultaneously under optimal parameters of the abiotic factors as set out in Ordinance 44 of the Ministry of Agriculture and Forests on the technological standards of main abiotic elements /temperature, humidity and speed of air movement, light intensity and content of toxic gases/. Biotic factors are regulated by implementing the prophylactic programs and optimization of the density of the economically beneficial species populations.

Trials are carried out with 80 laying hens divided into 4 equal groups of the ISA-Brown breed, at the age of 36 weeks for a period of 90 days. The ration contains $18 \%$ raw protein, $0,44 \%$ digestible phosphorous, 3,83\% calcium, 0,91\% lysine, $0,76 \%$, methionine + cysteine and exchanged energy of 2750 $\mathrm{kcal} / \mathrm{kg}$ fodder.

The following groups are made:

I group /control/ fed with combined fodder mixture prepared with all components included as per the recipe, containing $\mathrm{Pb} 0.45$ $\mathrm{mg} / \mathrm{kg}$ fodder and $\mathrm{Cd} 0.38 \mathrm{mg} / \mathrm{kg}$ fodder, which corresponds to the MRL (Maximum Residues Limit).
II group - fed with fodder containing lead and cadmium 2.5 times more than the $1^{\text {st }}$ group

III group - fed with fodder containing lead and cadmium 20 times more than the $1^{\text {st }}$ group

IV group - fed with fodder containing lead and cadmium 200 times more than the $1^{\text {st }}$ group

The biomass of the birds is measured at the beginning and at the end of the trial. Immediately after animals are slaughtered (6 animals per group), the organs are weighted and transported to the laboratory in containers with temperature of $2^{\circ} \mathrm{C}$. Bones are removed from the carcass and are weighted before and after drying.

The toxic chemical elements cadmium and lead are released in the potable water and the fodder at the beginning of the trial. The content of the two toxic elements in the tissues of the laying hens is measured after the end of the trial with atom-absorption spectrophotometer, type Spectra AA 220 Z Varian /AAC/, in accordance with the Jorchem method /1993/, Kirov's modification with wet mineralization.

The results are statistically processed by means of the statistics software Origin ${ }^{\circledR} 7.0$ SR0, V 7.0220 (B220) and the criterion of statistical reliability of all comparisons is $\mathrm{P}<$ 0.05 .

\section{Results and Discussion}

The details about lead content in the organs and tissues of the laying hens are presented in table 1 .

The average lead content in the liver of the hens from the $1^{\text {st }} /$ control/ group is 0.016 $\mathrm{mg} / \mathrm{kg}$ fresh mass and increases reliably $(\mathrm{P}<$ $0.05)$ in the $2^{\text {nd }}, 3^{\text {rd }}$ and $4^{\text {th }}$ group up to 0.033 , 
0.073 and $0.721 \mathrm{mg} / \mathrm{kg}$. Reliable differences in the quantity of lead in the liver also exist between the trial groups.

The lead accumulation, depending on the increased content in the ration, is intensive in kidneys too. In the kidneys of the birds from the control $/ 1^{\mathrm{st}} /$ group it is $0.013 \mathrm{mg} / \mathrm{kg}$ fresh mass, and statistically reliably $(\mathrm{P}>0.05)$ it increases to $0.072 \mathrm{mg} / \mathrm{kg}$ fresh mass in the $2^{\text {nd }}$ group, and increases to 0.153 and $0.784 \mathrm{mg} / \mathrm{kg}$ fresh mass in the $3^{\text {rd }}$ and the $4^{\text {th }}$ group respectively. With regard to trial groups, reliable difference between the $4^{\text {th }}$ and the $2^{\text {nd }}$ group is found.

The quantities of lead increase most significantly in the bone tissue, depending on the quantity of the ration /under the conditions of the trial/. Reliable $(\mathrm{P}<0.05)$ increase of the lead content is found in the $2^{\text {nd }}$, the $3^{\text {rd }}$ and the $4^{\text {th }}$ group. Lead in bones is more in comparison with the other bodies and tissues of the birds with regard to all groups, including the control group.

The lead content in the muscle tissue is relatively low and is less affected by its amount in the ration in comparison to the bones, liver and kidneys. Our results for the accumulation of lead in the muscle and bone tissue are the same as the results of other authors who have performed trials with other doses and other biological subjects - fattening hens - Stanchev /1988/, Baykov et al., /1996/, Erdogan et al., /2005/, turkeys - Finley et al., /1976/, Jeng et al., /1997/.

The lead content in the heart is relatively low and its values are close to the content in the muscle tissue.

The accumulation of lead in the lung is higher than in the liver, and the values are close to the data for the kidneys. These results are important for the practice, as literature does not contain data for the lead content in the lung and the heart of poultry, and the limited information refers to freely living birds. Burger et al., /2001/, Dong-Ha et al., /2002/, etc. found results, which are similar to ours with regard to the trends of lead accumulation in the body of freely living birds. The lead content in the muscle stomach is close to its content in the muscle and heart tissue. The smooth increase in the $2^{\text {nd }}, 3^{\text {rd }}$ and $4^{\text {th }}$ group remains, without extreme values that are typical for the $4^{\text {th }}$ group with regard to liver, kidneys and lung. The increased lead content in the muscle stomach of the $2^{\text {nd }}$ group (0.031) is not reliable in comparison to the control group (0.026), while its increase in the $3^{\text {rd }}$ $(0.053)$ and the $4^{\text {th }}$ group $(0.172)$ is reliable. Between the trial groups, the increased lead content is authentic between the $3^{\text {rd }}$ and the $4^{\text {th }}$ group and between the $2^{\text {nd }}$ and the $4^{\text {th }}$ group.

The increase of the amount of lead in the ration of the hens results in increase in the skin of up to $0.153,0.225$ and $0.342 \mathrm{mg} / \mathrm{kg}$ fresh mass, which is $7.65,11.25$ and 17.10 times increase in comparison to the control group $(0.020 \mathrm{mg} / \mathrm{kg}$ fresh mass).

Available literature does not contain data for the lead content in the skin of poultry and wild birds, except the study of Doganoc (1996) who specifies that the average lead content in the skin of the laying hens at different places in Slovakia is $0.21 \mathrm{mg} / \mathrm{kg}$ fresh mass, and of chickens kept for meat production it is 0.13 $\mathrm{mg} / \mathrm{kg}$ fresh mass.

The literature does not contain data for lead and cadmium content in the feathers of the poultry birds, and only of wild birds (Burger et al., /2001/, /2002/, Grue et al., /19845/. The results we have obtained show that the lead content is relatively high in the $1^{\text {st }}$ group and smoothly increases in proportion to the amount in the ration in the $2^{\text {nd }}$ and the $3^{\text {rd }}$ group, but remains relatively stable at 
increased levels of the toxic effector in the ration $/ 4^{\text {th }}$ group/.

The data about the cadmium content in the organs and tissues of the four groups of laying hens are described in table 2. The increase of cadmium in the ration increases its amount in all tested organs and tissues of poultry. The content of this toxic element is highest in the kidneys of the poultry in group 1 and in the other groups /2, 3, 4/ it increases $2.41 ; 8.93$ and 65.52 times respectively in comparison to the $1^{\text {st }}$ group. The difference in the cadmium content in the kidneys among the trial groups is reliable $(\mathrm{P}<0.05)$.

The accumulation of cadmium in the liver ranks second in terms of intensity /after kidneys/ of the poultry in all groups. The difference in the cadmium content in the liver between the control group and the trial groups and among the trial groups is reliable $(\mathrm{P}<$ $0.05)$.

The results of our trial are similar to the results from the experiments with other doses and under other trial conditions (fattening hens - Baykov et al., /1996/, Bial \& Ercag /2003/).

Cadmium accumulation in the bone tissue is lower in comparison to the other tissues and organs of the trial poultry: from the amount of $0.038 \mathrm{mg} / \mathrm{kg}$ in the control group it reaches up to 1.025 in $4^{\text {th }}$ group.

The amount of cadmium in the muscles of the poultry in the trial groups is in correlation with its content in the ration and is lowest /except in bones/ in comparison to the other tested tissues and organs of the poultry in the trial groups. The cadmium content in the muscles of the poultry in the control group is 0.103 $\mathrm{mg} / \mathrm{kg}$ fresh mass and increases reliably ( $\mathrm{P}>$ 0.05 ) to 0.137 in the $2^{\text {nd }}$ group, and increases with high statistical reliability up to 0.244 and $2.972 \mathrm{mg} / \mathrm{kg}$ in the $3^{\text {rd }}$ and the $4^{\text {th }}$ group, respectively. The cadmium content in the heart muscles is comparable with the amounts in the muscle tissue and is lower in comparison to the liver and kidneys of tested laying hens. The cadmium content in the muscle stomach is quite higher than in the skeleton muscles and the heart of the poultry in all groups, including in the control group. The literature does not contain data for the cadmium content in the heart and the muscle stomach of the poultry. The results of our trail of cadmium content in the bone and muscle tissue are similar with the data of other authors as a result of trials with other species and concentrations of the toxic factor in the living environment (Stanchev /1988/, Baykov et al., /1996/, Lisunova et al., /2003/).

The cadmium content in the lungs is 0,620 $\mathrm{mg} / \mathrm{kg}$ fresh mass for the poultry in the control group and increases to $0,877,0,958$ and 4.659 $\mathrm{mg} / \mathrm{kg}$ fresh mass for the $2^{\text {nd }}, 3^{\text {rd }}$ and $4^{\text {th }}$ group, respectively. The amount of cadmium in the skin of the poultry in the control group is comparable with its content in the muscle tissue, with analogical dynamics of the trial groups. Our results for the control group are similar to the data of Doganoc (1996).

During our trials we found that the accumulation of cadmium in the feathers is relatively high and the identified differences as statistically significant between separate groups, however the organotropism of cadmium in all groups is expressed in the liver, the kidneys and the muscle stomach. This data refutes the possibility of using feathers as a bioindicator for defining the cadmium content in the biocenosis, although Burger et al., /2001/, /2002/ suggests that due to the high content in the feathers of water birds, they may be used for the bioenvironmental monitoring.

A model of "mesocosm" type is developed, which allows to align the abiotic factors and 
the biotic relations, as well as the food resources for the 4 groups of aligned laying hens. There are differences only in the lead and cadmium content, and the $1^{\text {st }}, 2^{\text {nd }}$ and $3^{\text {rd }}$ group are bread with ration that contains amounts of lead and cadmium identified in our previous trials in a region with high technogenic Clark of the two toxic elements /trials with Hristev et al., /2002/ in a region close to Plovdiv/. The fourth group is given a ration with high doses of lead and cadmium, and do not demonstrate toxic effect on the poultry.

The trials with laying hens carried out under modelled conditions show that there are reliable differences in the organotropism of cadmium and lead and the intensity of their accumulation in the tested organs and tissues of the laying hens.

These differences define the principal objective of the trials - to develop criteria for chemical heterogeneity of the biosphere at the sub-organismal level, which will be applied for the management of agro-environmental systems for secondary biological production.

For a period of more than 40 years (from 1899 to 1924), with more than 5000 chemical analyses, Clark proved the chemical heterogeneity of the lithosphere and (found the average content of the ten major chemical elements spread in the surface layer (depth of up to $16 \mathrm{~km}$ ) of the lithosphere. In 1934 Fersman proposes the Clark criterion as a quantitative criterion to assess such heterogeneity.

Significant differences in the concentration of dispersed chemical elements in the lithosphere are found, which, to the opinion of Dobrovolskiy can be divided into the following groups:

Mn, $\mathrm{Cu}, \mathrm{Zn}, \ldots$... 100
Pb, Ni, Li, Sn, W, Be, U, Cr..... n. $100-$ n. 1000

Au, Mo, Co...n. 1000 - n. 10000

Hg, An...n. 10000 - n. 100000

Hydrosphere is also characterized with chemical heterogeneity, which is due to the introduction of chemical elements by means of water circumrotation, which passes through a lithosphere contact phase and changes the water's chemical composition.

During the $20^{\text {th }}$ century, Vernadsky identifies the chemical heterogeneity in the biotic components of the biosphere as well.

He proves that the different content of chemical elements is typical for the autotrophic and heterotrophic organisms, as well as among different species at the same trophic level, i.e. the chemical heterogeneity is a major feature of the entire biosphere. [Dobrovolskiy /1998/, Reylly /1980/, KabataPendias, A \& H. Pendias /1984/

Different criteria for assessment of chemical heterogeneity in biosphere are applied to the agrocenosis management, which are the basis for the management decisions regarding the efficient conversion of ration energy and nitrogen and with regard to the movement of biogenic elements of lithospheric origin within the system. /Stanchev /1988/, Baykov et al., /1996/, Kostadinova \& Petkov /2012/, Kostadinova /2013/, Kostadinova et al., /2013/. Until now we have applied two criteria for the anthropozoocenosis management:

With regard to the management of agroenvironmental systems aimed at food safety, we propose the criterion "distribution Clark" $/ \mathrm{Cd} /$, which defines the chemical heterogeneity of the biosphere at suborganism level. 
Table.1 Lead content in organs and tissues of laying hens (mg/kg fresh mass) and safety Clark /Cs/

\begin{tabular}{|c|c|c|c|c|c|c|c|c|c|}
\hline Groups & Liver & Kidneys & Lung & Heart & $\begin{array}{l}\text { Muscle } \\
\text { stomach }\end{array}$ & $\begin{array}{c}\text { Skeleton } \\
\text { muscles }\end{array}$ & Skin & Bones & Feathers \\
\hline $\begin{array}{c}\text { I } \\
\text { group }\end{array}$ & $\begin{array}{c}0.016 \pm \\
0.003 \\
\mathbf{0 . 0 3}\end{array}$ & $\begin{array}{c}0.013 \pm \\
0.003 \\
0.03\end{array}$ & $\begin{array}{c}0.027 \pm \\
0.019 \\
0.05\end{array}$ & $\begin{array}{c}0.018 \pm \\
0.007 \\
0.04\end{array}$ & $\begin{array}{c}0.026 \pm \\
0.005 \\
0.05\end{array}$ & $\begin{array}{c}0.030 \pm \\
0.008 \\
0.05\end{array}$ & $\begin{array}{c}0.020 \pm \\
0.003 \\
0.04\end{array}$ & $\begin{array}{c}0.124 \pm \\
0.019 \\
0.25\end{array}$ & $\begin{array}{c}0.183 \pm \\
0.044\end{array}$ \\
\hline $\begin{array}{c}\text { II } \\
\text { group }\end{array}$ & $\begin{array}{c}0.033 \pm \\
0.004 * \\
2-3 * \\
0.07\end{array}$ & $\begin{array}{c}0.072 \pm \\
0.048 \\
0.14\end{array}$ & $\begin{array}{c}0.065 \pm \\
0.019 \\
0.13\end{array}$ & $\begin{array}{c}0.026 \pm \\
0.006 \\
\boldsymbol{0 . 0 5}\end{array}$ & $\begin{array}{c}0.031 \pm \\
0.006 \\
\mathbf{0 . 0 6}\end{array}$ & $\begin{array}{c}0.037 \pm \\
0.010 \\
0.40\end{array}$ & $\begin{array}{c}0.153 \pm \\
0.037 \\
0.31\end{array}$ & $\begin{array}{c}0.178 \pm \\
0.022 * \\
2-3 * \\
0.31\end{array}$ & $\begin{array}{c}0.433 \pm \\
0.276\end{array}$ \\
\hline $\begin{array}{c}\text { III } \\
\text { group }\end{array}$ & $\begin{array}{c}0.073 \pm \\
0.017 * \\
3-4 * \\
0.15\end{array}$ & $\begin{array}{c}0.153 \pm \\
0.081 * \\
0.31\end{array}$ & $\begin{array}{c}0.110 \pm \\
0.026 * \\
3-4 * \\
0.31\end{array}$ & $\begin{array}{c}0.053 \pm \\
0.021 \\
0.106\end{array}$ & $\begin{array}{c}0.053 \pm \\
0.032 \\
3-4 * \\
0.11\end{array}$ & $\begin{array}{c}0.040 \pm \\
0.011 \\
\mathbf{0 . 4 0}\end{array}$ & $\begin{array}{c}0.225 \pm \\
0.144 \\
\boldsymbol{0 . 4 5}\end{array}$ & $\begin{array}{c}0.980 \pm \\
0.048^{*} \\
3-4^{*} \\
\mathbf{0 . 4 5}\end{array}$ & $\begin{array}{l}0.718 \pm \\
0.261 *\end{array}$ \\
\hline $\begin{array}{c}\text { IV } \\
\text { group }\end{array}$ & $\begin{array}{c}0.721 \pm \\
0.372 * \\
4-2 * \\
1.44\end{array}$ & $\begin{array}{c}0.784 \pm \\
0.432 * \\
4-2 * \\
1.57\end{array}$ & $\begin{array}{c}0.606 \pm \\
0.244 * \\
4-2 * \\
1.21\end{array}$ & $\begin{array}{c}0.062 \pm \\
0.027 * \\
0.124\end{array}$ & $\begin{array}{c}0.172 \pm \\
0.054 * \\
4-2 * \\
0.34\end{array}$ & $\begin{array}{c}0.055 \pm \\
0.003 * \\
4-2 * \\
0.55\end{array}$ & $\begin{array}{c}0.342 \pm \\
0.156 * \\
0.68\end{array}$ & $\begin{array}{c}14.656 \pm \\
4.708 * \\
4-2 * \\
0.68\end{array}$ & $\begin{array}{l}0.886 \pm \\
0.091 *\end{array}$ \\
\hline
\end{tabular}

* the difference in comparison to the control group is reliable $(\mathrm{P}<0.05)$;

$2-3 *$ the difference between the $2^{\text {nd }}$ and the $3^{\text {rd }}$ trial group is reliable $(\mathrm{P}<0.05 \mathrm{Cs}-$ with coefficient where 1 is considered admissible;

$2-4 *$ the difference between the $2^{\text {nd }}$ and the $4^{\text {th }}$ trial group is reliable $(\mathrm{P}<0.05)$ content in compliance with Regulation $/$ EC/ $1881 / 20063-4 *$ the difference between the $3^{\text {rd }}$ and the $4^{\text {th }}$ trial group is reliable $(\mathrm{P}<0.05)$. 
Table.2 Cadmium content in the organs and tissues of laying hens (mg/kg fresh mass) and safety Clark /Cs/

\begin{tabular}{|c|c|c|c|c|c|c|c|c|c|}
\hline Groups & Liver & Kidneys & Lung & Heart & $\begin{array}{c}\text { Muscle } \\
\text { stomach }\end{array}$ & $\begin{array}{l}\text { Skeleton } \\
\text { muscles }\end{array}$ & Skin & Bones & Feathers \\
\hline $\begin{array}{c}\text { I } \\
\text { group }\end{array}$ & $\begin{array}{c}2.641 \pm \\
0.574 \\
5.28\end{array}$ & $\begin{array}{c}6.674 \pm \\
0.250 \\
6.67\end{array}$ & $\begin{array}{c}0.620 \pm \\
0.159\end{array}$ & $\begin{array}{c}0.081 \pm \\
0.028\end{array}$ & $\begin{array}{c}2.287 \pm \\
0.283\end{array}$ & $\begin{array}{c}0.103 \pm \\
0.051 \\
2.06\end{array}$ & $\begin{array}{c}0.050 \pm \\
0.027\end{array}$ & $\begin{array}{c}0.038 \pm \\
0.009\end{array}$ & $\begin{array}{c}0.280 \pm \\
0.017\end{array}$ \\
\hline $\begin{array}{c}\text { II } \\
\text { group }\end{array}$ & $\begin{array}{c}7.563 \pm \\
1.717 * \\
15.13\end{array}$ & $\begin{array}{c}16.131 \pm \\
0.853^{*} \\
2-3^{*} \\
16.13\end{array}$ & $\begin{array}{c}0.877 \pm \\
0.122\end{array}$ & $\begin{array}{c}0.134 \pm \\
0.059 \\
2-3 *\end{array}$ & $\begin{array}{l}4.968 \pm \\
0.875 *\end{array}$ & $\begin{array}{c}0.137 \pm \\
0.045 \\
2.74\end{array}$ & $\begin{array}{l}0.107 \pm \\
0.005 *\end{array}$ & $\begin{array}{c}0.102 \pm \\
0.079\end{array}$ & $\begin{array}{l}0.469 \pm \\
0.109 *\end{array}$ \\
\hline $\begin{array}{c}\text { III } \\
\text { group }\end{array}$ & $\begin{array}{c}13.184 \pm \\
3.829 * \\
3-4^{*} \\
26.37\end{array}$ & $\begin{array}{c}59.569 \pm \\
12.260 * \\
3-4 * \\
59.60\end{array}$ & $\begin{array}{c}0.959 \pm \\
0.057 * \\
3-4 *\end{array}$ & $\begin{array}{c}0.335 \pm \\
0.087 * \\
3-4 *\end{array}$ & $\begin{array}{l}6.050 \pm \\
2.186 *\end{array}$ & $\begin{array}{c}0.244 \pm \\
0.145 \\
3-4 * \\
4.88\end{array}$ & $\begin{array}{c}0.200 \pm \\
0.094 * \\
3-4 *\end{array}$ & $\begin{array}{c}0.123 \pm \\
0.041 * \\
3-4 *\end{array}$ & $\begin{array}{l}0.959 \pm \\
0.374 *\end{array}$ \\
\hline $\begin{array}{c}\text { IV } \\
\text { group }\end{array}$ & $\begin{array}{c}152.800 \pm \\
31.979 * \\
4-2 * \\
305.60\end{array}$ & $\begin{array}{c}437.331 \pm \\
78.504 * \\
4-2 * \\
437.33\end{array}$ & $\begin{array}{c}4.659 \pm \\
0.445 * \\
4-2 *\end{array}$ & $\begin{array}{c}3.760 \pm \\
0.168 * \\
4-2 *\end{array}$ & $\begin{array}{l}22.414 \pm \\
13.584 *\end{array}$ & $\begin{array}{c}2.972 \pm \\
0.302 * \\
4-2 * \\
59.44\end{array}$ & $\begin{array}{c}3.186 \pm \\
0.217 * \\
4-2 *\end{array}$ & $\begin{array}{c}1.025 \pm \\
0.334 * \\
4-2 *\end{array}$ & $\begin{array}{c}2.333 \pm \\
0.452 * \\
4-2 * \\
4-3 *\end{array}$ \\
\hline
\end{tabular}

The difference in comparison to the control group is reliable $(\mathrm{P}<0.05)$

$2-3^{*}$ the difference between the $2^{\text {nd }}$ and the $3^{\text {rd }}$ trial group is reliable $(\mathrm{P}<0.05)$

$2-4 *$ the difference between the $2^{\text {nd }}$ and the $4^{\text {th }}$ trial group is reliable $(\mathrm{P}<0.05)$

$\mathrm{Cs}-$ in units of TLM (threshold limit values) as per Ordinance 5/20015 and Regulation /EC/ 1881/2006 
Table.3 Evaluation of the lead distribution by means of the distribution Clark $(\mathrm{Cd})$ in the organs and tissues of the laying hens

\begin{tabular}{|c|l|l|l|l|l|c|c|c|c|}
\hline Groups & Liver & Kidneys & Lung & Heart & $\begin{array}{c}\text { Muscle } \\
\text { stomach }\end{array}$ & $\begin{array}{c}\text { Skeleton } \\
\text { muscles }\end{array}$ & Skin & Bones & Feathers \\
\hline I & 0.291 & 0.236 & 0.491 & 0.327 & 0.473 & 0.545 & 0.364 & 2.255 & 3.327 \\
\hline II & 0.333 & 0.727 & 0.657 & 0.263 & 0.313 & 0.374 & 1.545 & 1.798 & 4.374 \\
\hline III & 0.316 & 0.662 & 0.476 & 0.229 & 0.229 & 0.173 & 0.974 & 4.242 & $\mathbf{3 . 1 0 8}$ \\
\hline IV & $\mathbf{0 . 3 8 5}$ & $\mathbf{0 . 4 1 8}$ & $\mathbf{0 . 3 2 3}$ & $\mathbf{0 . 0 3 3}$ & $\mathbf{0 . 0 9 2}$ & $\mathbf{0 . 0 2 9}$ & $\mathbf{0 . 1 8 2}$ & $\mathbf{7 . 8 1 7}$ & $\mathbf{0 . 4 7 3}$ \\
\hline
\end{tabular}

Table.4 Evaluation of the cadmium distribution by means of the distribution Clark $(\mathrm{Cd})$ in the organs and tissues of the laying hens

\begin{tabular}{|c|c|c|c|c|c|c|c|c|c|}
\hline Groups & Liver & Kidneys & Lung & Heart & $\begin{array}{c}\text { Muscle } \\
\text { stomach }\end{array}$ & $\begin{array}{c}\text { Skeleton } \\
\text { muscles }\end{array}$ & Skin & Bones & Feathers \\
\hline I & 8.777 & 16.670 & 1.628 & 0.223 & 6.309 & 0.309 & 0.255 & 0.362 & 2.691 \\
\hline II & 11.815 & 18.935 & 1.085 & 0.175 & 6.435 & 0.190 & 0.260 & 0.455 & 2.120 \\
\hline III & 10.457 & 35.490 & 0.602 & 0.218 & 3.977 & 0.173 & 0.246 & 0.279 & 2.198 \\
\hline IV & $\mathbf{1 0 . 7 8 9}$ & $\mathbf{2 3 . 1 9 5}$ & $\mathbf{0 . 2 6 1}$ & $\mathbf{0 . 2 1 9}$ & $\mathbf{1 . 3 1 2}$ & $\mathbf{0 . 1 8 7}$ & $\mathbf{0 . 3 5 0}$ & $\mathbf{0 . 2 0 9}$ & $\mathbf{0 . 4 7 6}$ \\
\hline
\end{tabular}

This recommendation is based on the fact that until now literature provide data for the lead and cadmium content in tested organs and tissues of different animals only (Dong-Ha et al., /2002/, Korenekova et al., /2002/, Massanyi et al., /2000/, Wayland et al., 12001/. The information available does not allow for the assessment of the distribution of the toxic factor in the organs and systems and to evaluate the organotropism of the tested effector.

The quantitative criterion "Distribution Clark" $(\mathrm{Cd})$ is defined as a ratio between the content of the toxic element in the tested organ or tissue (in $\mathrm{mg} / \mathrm{kg}$ of fresh mass) to the average content of the tested chemical element in the organism /average Clark/. The average Clark is defined as a ratio between the total amount of tested element in all tested organs and tissues to the biomass. The use of the $\mathrm{Cd}$ criterion for the management of agroenvironmental systems allows for practical issues to be solved with regard to the control of the secondary biological production - objective evaluation of the target organs where the accumulation of the respective factor is highest and should be included in the bioenvironmental monitoring. Cd further the quality of production originating from regions with high Clark of toxic elements in the lithosphere, where organs and tissues, in which the models identify as accumulating minimum amounts of the respective risk chemical factors, that is allowed for consumption.

When analyzing the data in table 3, we find that the increase of the lead dose in the ration results in differences in its redistribution.

$\mathrm{Cd}$ in the liver is 0.291 for the control group and increases by 1.14 in the $2^{\text {nd }}$ group and by 1.08 times in the $3^{\text {rd }}$ group, while the increase in the $4^{\text {th }}$ group is 1.32 times. This data shows that regardless of the differences in the amounts of lead in the ration and the significant differences in the content in the liver of the poultry in the 4 groups, which are statistically significant, $\mathrm{Cd}$ remains the same. 
$\mathrm{Cd}$ in the kidneys is 0.236 in the control group and increases up to $0.727,0.662$ and 0.418 , which is $3.08,2.81$ and 1.77 times increase in the $2^{\text {nd }}, 3^{\text {rd }}$ and $4^{\text {th }}$ group, respectively. Such increase is not proportional to the lead values found in the tested organ, which increase 65.3 times from the $1^{\text {st }}$ to the $4^{\text {th }}$ group.

The values of $\mathrm{Cd}$ of lead in the heart muscles, the muscle stomach and the skeleton muscles decrease in the trial groups in comparison to the control group. The dynamics in the skeleton muscles is $0.545,0.374,0.173$ and 0.029 in the $1^{\text {st }}$ to $4^{\text {th }}$ group, respectively, which indicates that in case of high content of the toxic factor in the environment /water and fodder/ redistribution of lead occurs, whereas the main part of it is deposited in the bones. The values of $\mathrm{Cd}$ in the skin of the poultry in the control group is 0.364 and increases up to 1.545 and 0.974 in the $2^{\text {nd }}$ and the $3^{\text {rd }}$ trial group, respectively, which correspond to 4.24 and 2.68 times increase in comparison to the control group. The value of $\mathrm{Cd}$ in the $4^{\text {th }}$ trial group decreases to 0.182 , which is 2 times decrease in comparison to the $1^{\text {st }}$ group.

The highest value of $\mathrm{Cd}$ of lead is found in the feathers of the animals in the control group and in the $2^{\text {nd }}$ group, where it is 3.327 and 4.374 , respectively. In the $3^{\text {rd }}$ and the $4^{\text {th }}$ group the values of $\mathrm{Cd}$ are 3.108 and 0.473 .

The distribution Clark of the lead in the bone tissue of poultry in the control group is 2.225 and decreases to 1.798 for poultry in the $2^{\text {nd }}$ group (1.24 times decrease) and then it increases with high intensity up to 4.242 and 7.817 for the poultry in the $3^{\text {rd }}$ and the $4^{\text {th }}$ trial group, respectively, which is 1.91 and 3.51 times increase in comparison to the control group.

The application of $\mathrm{Cd}$ shows typical dynamics of lead distribution in the tested organs and tissues. In some of them /liver, kidneys and bones/ Cd increases with the increase of the toxic factor in the ration, which makes them reservoirs of lead in the body of the hens. A phase effect is also found - in the kidneys, the lung, and the muscle stomach there is an increase in the $2^{\text {nd }}$ and the $3^{\text {rd }}$ group and then a decrease in the $4^{\text {th }}$ group, i.e. there is a redistribution at organismal level, depending on the amount of the toxic factor at the entrance of the system /fodder and water/. The study of the mechanisms of this specificity in the distribution is subject to future research, but most probably the phase effect is due to the substrate induction /due to the existence of relatively high doses of the factor at the entrance of the system/ of the mechanisms being the base of the chemical hemostasis of the tested organs and the different options for adequate reaction upon increase of the toxic factor in the living environment.

Data in table 4 show that the increase of the cadmium dose in the ration of the laying hens results in some specific features of the distribution Clark. The distribution Clark of cadmium in the liver is 8,777 for poultry in the control group and increases in the $2^{\text {nd }}, 3^{\text {rd }}$ and $4^{\text {th }}$ trial group up to $11,815,10,457$ and 10,789 , respectively. We should note that the Clark of cadmium in the liver of the animals in the $3^{\text {rd }}$ and the $4^{\text {th }}$ group decreases unreliably in comparison to the $2^{\text {nd }}$ group but there is a trend to reach a relatively constant value of the toxic element, irrespective of the differences existing in its amount at the entrance of the system /fodder + drinking water/. The values of $\mathrm{Cd}$ in the kidneys of the poultry increase with the increase of the cadmium dose in the ration of the $2^{\text {nd }}$ and the $3^{\text {rd }}$ group, but decrease in the $4^{\text {th }}$ group. From 16,670 in the control group it increases to $18,935,35,490$ and 23,195 in the other three trial groups, respectively. The values of the cadmium distribution Clark in the skin 
increase, depending on the cadmium doze in the ration, however relatively low degree of bioaccumulation is found - values are less than one in all groups. The values of the cadmium distribution Clark in the other tested organs and tissues decrease upon increase of its dose in the ration. In the muscle stomach of the poultry the values of cadmium $\mathrm{Cd}$ in the $1^{\text {st }}$ group are approximately the same as those of the skeleton muscles and in both tested muscle structures $\mathrm{Cd}$ decreases upon increase of the toxic element in the portion. The values of the cadmium distribution Clark in the heart of the animals in the $1^{\text {st }}, 2^{\text {nd }}$ and $3^{\text {rd }}$ group do not change significantly, but sharp decrease is found in the $4^{\text {th }}$ group. The value of the cadmium $\mathrm{Cd}$ in the bone tissue of the poultry is less than one. Cd of poultry in the control group is 0,362 and increases up to 0,455 in the $2^{\text {nd }}$ trial group and then decreases to 0,279 and 0,209 in the $3^{\text {rd }}$ and $4^{\text {th }}$ trial group, respectively. $\mathrm{Cd}$ in the feathers of the poultry is bigger than one in the control group and in the $2^{\text {nd }}$ and $3^{\text {rd }}$ trial group, and in the $4^{\text {th }}$ group it is less than one.

Studies show two main specificities of the cadmium distribution at organ level: some of the organs /liver and kidney/ preserve their chemical homeostasis and although the cadmium content in the trail groups increases, the intensity of such increase is small. In the lung, muscle stomach, bone muscles and feathers, we find relative decrease of $\mathrm{Cd}$ in proportion to the increase of the cadmium in the ration. With regard to heart, bones and skin the chemical homeostasis is preserved, irrespective of the amount of cadmium in the system's inflow.

The safety Clark (Cs) is used to define and chemical heterogeneity at sub-organism level and this indicator is applied to evaluate the accumulation of toxic elements in the secondary biological production as human nutritional resource. This criterion is defined by dividing the content of the toxic factor in $\mathrm{mg} / 1 \mathrm{~kg}$ of fresh secondary biological product by the regulated maximum content in the same quantity, in accordance with the legal regulations applicable in the country. When analyzing those results in accordance with the Cs criterion, we should bear in mind that such criterion is developed to facilitate the control of food products of animal origin. The interpretation of Cs is very simply: in case of values exceeding 1, the product is dangerous for human health /red marking/, and in case of values less than 1 /green marking/ - it is safe. This interpretation is an alternative of the existing practice to use different dimensions and different references: $\mathrm{mg} / \mathrm{kg} ; \mathrm{mcg} / \mathrm{kg} ; \mathrm{g} / \mathrm{ton}$, etc. Furthermore, the control laboratories are required to update the information about the maximum residues limit /MRL/ of several toxic factors in food.

Our trials are governed by the legal regulations applicable in the country and the EU: Ordinance №5/09.12.2015 of the Ministry of Health that implements Regulation /EC/ 1881/2006. They set out differentiated requirements with regard to cadmium and lead for different food resources:

Lead: in poultry meat MRL $0.10 \mathrm{mg} / \mathrm{kg}$; subproducts $-0.50 \mathrm{mg} / \mathrm{kg}$

Cadmium: in poultry meat $0.050 \mathrm{mg} / \mathrm{kg}$; in liver $0.50 \mathrm{mg} / \mathrm{kg}$; in kidneys $-1.0 \mathrm{mg} / \mathrm{kg}$

The studies show the principled options to apply the Cs criterion for the control of food safety. The trials we carried out identified imperfections and omissions in the applied legal regulations. The trials are carried out under modelled conditions where all technological requirements and nutrition standards are observed. While observing the MRL standards for lead and cadmium in the ration with lead $\mathrm{Cs}$ in all organs and tissues 
intended for food, $\mathrm{Cd}$ is less than 1 in the first /control/group and increases in proportion to the amount of lead in the ration, i.e. Cs shows that the tested products of animal origin in the $1^{\text {st }}$ group are safe for human health, and that differences are observed in the other groups, which allow further specification of the hygiene assessment. The results from the application of the cadmium Cs are different. Legal regulations are limited up to meat, liver and kidneys, to MRL $0.050 \mathrm{mg} / \mathrm{kg} ; 0.5 \mathrm{mg} / \mathrm{kg}$ and $1.0 \mathrm{mg} / \mathrm{kg}$, respectively. Although the requirements for cadmium amount at the entrance of the system are observed, $\mathrm{Cd}$ in all tested organs and tissues /being subject to regulation/ exceeds 1, i.e. they pose a risk to the consumer. With these results we would like to emphasize on the second main guidance for the use of the Cs criterion - to be used as corrective of applied standards and the trials carried out under modeled conditions to be the basis for adjustment of these standards. This thesis is based on the fact that the cadmium MRL in horse meat is $0.2 \mathrm{~m}$, in contrast to all other meats where it is $0.05 \mathrm{mg} / \mathrm{kg}$, although MRL of animals at the same trophic level is stipulated and the same value of MRL should be proposed. The MRL set out for cereals - $02 \mathrm{mg} / \mathrm{kg}$, and for nutritional supplements $-3.0 \mathrm{mg} / \mathrm{kg}$, is also ground for revaluation.

The obtained results allow to make the following conclusions:

The "distribution Clark" criterion allows presenting organotropism in accessible form and using it for the evaluation of possibilities to use different organs and systems in the bioenvironmental monitoring and in the assessment of food safety.

The differences in the degree of distribution of lead and cadmium give new explanations for the bioaccumulation of the two toxic elements, and for the significant differences in their accumulation in the tested organs, respectively.

The criterion "safety Clark" Cs allows presenting the risk of existence of toxic elements in the products of animal origin in an accessible form, whereas values below 1 are considered safe.

Obtained results show that it is expedient to update the legal regulations for cadmium MRL based on the model trials, as MRL set out in Ordinance №5/2015 are incomplete and do not correspond to the values of cadmium actually measured under modelled conditions in the tested products from laying hens intended for human food.

\section{References}

Baykov, B, Kirov, K., Guguva, M., Zaharinov, B., Popova, I., Krynski, A., Karim, A., Penkov,D., Hristev, H. 2005. A new concept for the bioaccumulation of lead and cadmium along a food chain with farm animals. ISAH 2005 Warsaw, Poland. Vol.2

Baykov, B, M. Stayanov and M. Gugova. 1996. Cadmium and Lead bioaccumulation in male chickens for high food concentrations. Toxicoligicl and Environmental Chemistry. Vol. 54. pp. 155-159.

Baykov, B. 1994, An objective method for assessement of the movement of chemical elements in anthropogenic ecosytems (domestic animal ferms), Toxicol. Environ. Chem, 49, 119-121

Bilal. T, E. Ercag. 2003. Retention of cadmium in the tissues of broiler chicks by dietary supplemental microbial phytase. Vet. Med.-Czech, 48(7), 199205.

Burger. J, K. Gaines, C. Lord, I. Brisbin, S. Shukla and M. Gochfeld. 2002. Metal levels in Raccoon tissues: Differences 
on and off the department of energy's savannah river site in south Carolina. Environmental Monitoring and Assessment, vol.74: 67-84.

Burger. J, T. Shukla, C. Dixon, S. Shukla, M. Mcmahon, R. Ramos and M. 2001. Gochfeld. Metals in feathers of sooty tern, white tern, gray-backed tern and brown noddy from Islands in the North Pacific. Environmental Monitoring and Assessment, vol.71: 71-89.

Doganoc. D. Z. 1996. Distribution of lead, cadmium and zinc in tissues of hens and checkens from Slovenia. Bul. Environ. Contam. Toxicol. Vol. 57, pp. 932-937.

Dong-Ha N,, Doo-Pyo Lee and Tae-Hoe Koo. 2002. Comparison of heavy metal concentration and reproduction of Feral Pigeons (Columba livia) between Urban and Industrial complex areas from Koria. Korean J. Ecol. Sci., 1(3): 159164.

Erdogan Z, S. Erdogan, T. Aksu, E. Baytok and H. Turkey. 2005. The effect of dietary lead exposure and ascorbic acid on performance, lipid peroxidation satus and biochemical parameters of broilers. Turk. J. Vet Anim. Sci. vol 29, pp 10531059.

Finley. M and M. Dieter. 1976. Sublethal effect of chronic Lead ingestion in Mallard ducks. Journal of toxicology and environmental health, vol.1: 929937.

Fox S, M, R. Jacobs, A. Lee Gones and Bert Fry. 1979. Effects of nutritional factors on metabolism of dietary Cadmium at levels similar to those of man. Environmental Health Perspectives. Vol.28, 107-114.

Grue. C, T. Oshea and D. Hoffman 1984. Lead concentrations and reproduction in Highway-nesting barn Swallows. The Condor, vol. 86, pp. 383-389.

Jeng. S, S. Lee, Y. Liu, S. Yang and P. Liou. 1997. Effect of Lead ingestion on concentration of Lead in Tissues and eggs of laying Tsaiya Ducks in Taiwan. Poultry Science, vol.76:13-16.

Kabata-Pendias, A \& H. Pendias, Trace element in Soil and Plants, CPC Press Inc. Florida, 28,1984

Korenekova. B, A. Jackova, J. Kottferova, P. Siklenka, M. Skalicka, M. Korenek. 2002a. Effect of Vitamin D3 on cadmium retention by Laying Hens. Taylor \& Francis AS, part of Taylor \& Francis Group, vol 52, No 2, 81-84.

Kostadinova, G. N. Georgieva, Z. Yaneva, G. Petkov, M. Todorova, Ch. Miteva, 2013. Tundzha river water quality as a source for irrigation in agriculture. Bulgarian Journal of Agricultural Science, vol. 19, 4, 635-643.

Kostadinova, G., 2013. Sanitary hygienic assessment of drinking water from underground source at a pig farm, Agricultural Science and Technology, vol. 5, No 4, 448-454.

Kostadinova,G., G. Petkov, 2012. Sustainable Development of Agroecosystems and Environmental Protection in Bulgaria. Proceeding of International Conference Ecology - Interdisciplinary science and practice, 25-26 October, 2012, Sofia, Part I, PublishScieSet-Eco-Publisher, pp. 310-317.

Lisunova. L, V. Tokaver and A. Lisunova. 2003. Influence of cadmium on physiological parameters and efficiency of chickens-broilers. Proceedings of the first international conference on environmental research and assessment, Bucharest, Romania, March 23-27.

Massanyi. P, L. Bardos, R. Toman, S. Hluchy, J. Kovacik and N. Luhac. 2000 . Distribution of cadmium and its effects on the organ concentrations of retinoids and beta-carotene. $6^{\text {th }}$ internet world congress for biomedical sciences, February 14-25. 
Reylly, C., Metal contamination of Food, Applied Science Publ., London,1980

Wayland. M, A. Garcia-Rernandez, E. Neugebauer and H. Gilchrist. 2001. Contaminations of cadmium, mercury and selenium in blood, liver and kidney of common eider ducks from the Canada Arctic. Environmental Monitoring and Assessment, vol.71: 255-267.
Добровольский, В. В., Основы биогеохимии, М., Высшая школа, 1998

Одум, Ю. 1986. Экология, М., Мир

Станчев Х. 1988. Проучвания върху биологичното действие на олово и кадмий при бройлери. Дисертация. София.

\section{How to cite this article:}

Veselin Kirov, Abdul Karim Hallak, Alexander Tchoukanov and Bayko Baykov. 2018. New Criteria for Chemical Heterogeneity of the Biosphere: Distribution of Cadmium and Lead in Laying Hens. Int.J.Curr.Microbiol.App.Sci. 7(06): 1479-1491

doi: https://doi.org/10.20546/ijcmas.2018.706.176 